\title{
Márta Csabai
}

\section{Amor fati or posttraumatic growth? The case of Etty Hillesum in the time of the Holocaust}

\section{Summary}

Almost four decades after her death in Bergen-Belsen, the young Dutch woman, Etty Hillesum's diaries were published in 1981 and since then have received intense attention from the general public, and some reflections from philosophical, theological and psychological theorizing as well. The diaries reveal a deep struggle for personal independence against the unprecedented threats of the strengthening Nazi oppression. Influenced by Julius Spier, a charismatic psycho-chirologist, who was a therapist, a father/figure, lover and mentor for her, writing became Hillesum's outlet, and a vehicle for her spiritual liberation and personality development. One of the most interesting and paradoxical aspect of her diaries is that she could realize a substantial improvement of her self-coherence and personal integrity through her reflections about existential themes in an actually life-threatening, liminal situation. The chapter gives an overview of Etty Hillesum's writings in the context of her life-history and personality development; in the light of current psychological theories of posttraumatic growth, and also in the frame of the philosophical concept, the ,flow of the presence" of Eric Voegelin. The analysis might contribute to the understanding of the paradoxical positive reactions which help certain sufferers of extreme stresses and serious traumas to cope with the stress and to reach personality development and post-traumatic growth. Through the case of Etty Hillesum we might also examine the methodological question whether the present-tense narratives of self-experiences might serve as sufficient resources for psychobiographies.

Keywords: diary, holocaust, trauma, personal growth, spirituality

\section{Introduction and family history}

In 1981 the diaries of the Holocaust victim, Etty Hillesum, written between 1941 and 1943, appeared for the first time under the title Het verstoorde leven [An Interrupted Life], followed by a collection of her letters from the Westerbork Nazi camp, before her deportation to Auschwitz. A complete edition of Hillesum's approximately 100 pages of letters and 600 pages of diaries was published in Dutch in 1981 and translated into English in 1983. The confessional letters and diaries describe this exceptional young woman's - "the Dutch Anne Frank's" - spiritual growth and awakening during the Holocaust and her paradoxical relationship with the charismatic "psycho-chirologist", Julius Spier. Hillesum's writings provoked very strong and divisive existential, ethical, psychological and political dilemmas. The enormous public interest for her case 
facilitated the translation of the diaries into 67 languages and the 1986 opening of the Etty Hillesum Research Centre (EHOC) in Middelburg, the Netherlands. The diaries were offered to the publisher of the Dutch edition by professor Klaas A.D. Smelik, whose father, the writer Klaas Smelik received them trust from Hillesum before her deportation to Auschwitz.

The diaries and letters follow the identity development of a young woman and hold mirror up to a process which tragically presents how totalitarian ideology can destroy personal freedom. Paradoxically, they also demonstrate the way by which inner spiritual experience, the self-imposed community with fellow sufferers, and the feeling of connectedness might guarantee always, in all circumstances, the inviolable uniqueness and validity of human experience.

The central concept of Hillesum's writing is "inner life" (het innrlijk leven), which can be found on more than 200 pages of the original diaries: inner richness, inner horizon, inner reality, inner space, inner world, inner uttermost, etc. In her first diaries in 1941 she says that she feels it difficult to formulate her feelings but she wants to write for that very reason to be able to enter into the essence of existence.

Etty (Esther) Hillesum was born on 15th of January in 1914. Her father was a headmaster and professor of classical languages in Deventer. Her mother's family moved to the Netherlands from Russia, escaping from the persecutions of Jews. Though her grandfather was a rabbi of high rank, Etty considered herself an assimilated woman up to the time the persecutions started also in Holland during the war. This experience strengthened her Jewish identity and the feeling of community with the fate of Jews. Also that was one of the reasons why she did not hide or escape.

Etty called the family's home a madhouse. One of her brothers, Jacob (Jaap) was a talented medical researcher but suffered from psychiatric problems, presumably schizophrenia. The other brother, Michael (Mischa) as a child was considered as one of the most promising pianists of Europe but also became psychotic at the age of 16. In 
1943 the whole family had to move to Amsterdam, as all the Jewish citizens that time in the Netherlands. The family was deported to Aushwitz on 7th of September in 1943. The parents were sent to the gas chamber on that day, and Etty's death was reported by the Red Cross on November 30. Her youger brother died in March of 1944, and the older brother, who was transported to Bergen-Belsen, survived the concentration camp, but died on the way back home after the war.

Her acquaintances described Etty as a „typical Russian woman”: always busy, sometimes happy, other times sad, once expressive then chaotic (Coetsier, 2008). Some friends thought her changes of mood, phantasizing and eroticism rather infantile. She studied law, Russian language, and then psychology, but after 1942 she was not allowed to frequent university. She was an independent mind already at the time of starting her first diary, but full of uncertainty:

I don't know how to settle down to my writing. Everything is still much too chaotic, and I lack self-confidence, or perhaps the urgent need to speak out. I am still waiting for things to come out and find a form of their own accord. But first I myself must find the right pattern, my own pattern (Hillesum, 1996, 32).

\section{An unusual therapy with Julius Spier}

Probably the most influential person in Etty's life was the psycho-chirologist Julius Philipp Spier (1887-1942) whom she mentions as ' $S$ ' in her diaries. Actually the initiative of the diary itself was inspired by this relationship: the first note is a letter to Spier from March 1941. Etty spoke a very good German which they used in their communication with Spier. Several notes of the diary written in German gives evidence of Spier's influence on of her writing and personal development.

Spier left behind a successful business career in order to devote his life a new "science" psycho-chirology. Spier had been a client of Jung, studied psychotherapy with him, and was supported by Jung who considered him a promising candidate for chirology (hand- 
analysis). Spier started his practice in Berlin in 1930. In 1934 he divorced from his wife and in 1937 moved to the Netherlands as he could not stay in the Nazi Germany any longer. His fiancée, Hertha Levi also left Berlin and moved to London. They continued they relationship through correspondence, so Spier's relationship with Etty Hillesum could remain hidden from Hertha (Woodhouse, 2009).

Spier was considered as the most influential chirologist - hand analyst- of his time. After his studies in medicine and psychiatry he started to give seminars in the new "science", psycho-chirology for medical doctors and psychologists in Berlin and Zurich, trying to connect chirology with psychoanalysis. In his posthumous book (Spier, 1944) which was marked out for the first volume of a trilogy, he wanted to establish a theory and method by which early childhood psychosexual and developmental problems could have been detected and treated to prevent later neurosis.

Spier was an amateur singer and met Etty at a house concert where Etty's brother was the pianist. Spier's grandiose personality overwhelmed Etty and she checked in for therapy with him. Though Spier was a man with a strange look whom Etty described as an ugly, old kobold, his voice and the radiation of his personality held Etty spellbound, and she hoped that this "great, warm man" would help her to "collect her broken fragments". Etty was depressed, anxious, and compulsive. She needed an Aspirin and two hours sleep after lunch every day. She also suffered from eating disorders, panic attacks, feelings of emptiness, inferiority, and inability to make decisions (Baur, 1997).

Spier was an admitted womanizer, whose students were mainly women whom he not only seduced, but thanks to his outstanding empathy he could also teach to recognize their inner virtues. After starting their therapy, Etty soon became his secretary, and thereafter his lover. Spier applied an unusual therapeutic technique, naked wrestling, as an addition to psycho-chirology. He meant it a special "sensitivity training" for enhancing female sexuality and body consciousness, and applied it in order to get a picture of his clients' physical, emotional and mental state, and to help them to get closer 
to their own thoughts and feelings. Etty wrote the following about the start of the "wrestling cure":

That was no doubt why he began to test my physical strength in a sort of wrestling match. It was apparently more than adequate, for remarkably enough, I floored the man, big though he was. All my inner tensions, the bottled-up forces, broke free, and there he lay, physically and also mentally, as he told me later, thrown. No one had ever been able to do that to him before, and he could not conceive how I had managed it. His lip was bleeding. I was allowed to dab it clean with eau de cologne, an embarrassingly intimate thing to do. But then he was so "free," so guileless, so open, so unaffected in his movements, even as we tumbled about together on the ground. And even when I, held tightly in his arms and finally tamed, lay under him, he remained "objective," pure, while I surrendered to the physical spell he emanated. It all seemed so innocent, this wrestling, new and unexpected, and so liberating. I t was not until later that it took hold of my fantasies. (Hillesum, 1996, 6-7).

For the second time, however, both of them got involved:

But the second time we wrestled, things were quite different. Then he too showed passion. And when at one point he lay groaning on top of me, for just a brief moment, and made the oldest convulsive movement in the world, then the lowest of thoughts rose up in me like a miasma from a swamp, something like: "A funny way of treating patients you have, you get your pleasure out of it and you get paid for it as well even if it is just a pittance."... In the end my rebelliousness died down and there was a sense of closeness between us, and more personal contact than we may ever have again. But while we were still lying on the floor, he said, "I don't want to have a relationship with you." And he added, "I must tell you honestly, I find you very attractive." (Hillesum, 1996, 21) 
For the reader of our day this therapeutic technique is obviously astounding and ethically inacceptable, but in the context of its time it can be evaluated not only from a moral aspect. This is well-known that between the two world-wars the development of psychoanalysis has brought with itself several dilemmas which resulted in the formulating of the need for a psychoanalytically founded, holistic, psychosomatic care, which contained the important element of treating the body and soul together (Mizrachi, 2001). One of the most prominent representatives of this approach was Georg Groddeck who applied massage parallel with psychotherapy, and considered the strong, suggestive presence of the therapist as an important determinant of therapeutic effect (Avila, 2003).

Spier's psycho-chirology and the technique of naked wrestling were directly connected to the starting body psychotherapy movement of the era. One of the most important centers of these movements was Berlin in the 1920s and '30s. That was the time when new initiatives appeared for the complex treatment of body and mind by gymnastics, respiration therapy, massage, homeopathy and balneotherapy, combined with psychotherapy. Julius Spier was open for these new approaches, e.g. to homeopathy. He lived a very healthy life: didn't smoke, drink, had a vegetarian diet and did exercise each day. Etty followed him with physical exercises, body hygiene and respiration practices.

Another possible inspiration for Spier's method might be Wilhelm Reich's work (Reich, 1963). Reich tried to 'liberate' the psychological resistances, the 'character armour' and the repressed instinct-energies through techniques directed to the body, the muscles, respiration and movement. The treatment of sexual energies, the 'sexual economy' got an explicit role in his method. As a main practical principle he emphasized that the goal of psychoanalytic therapy was the recovery of the 'orgastic potential', through the canalization of obstructed sexual energies. It had been also Reich's intervention that for the sake of proper muscle contractions or relaxation patients took part in therapy naked, or in underclothes, and the therapist could also touch their bodies. This was meant both as an innovation of the therapeutic technique but also a critical reflection on the contemporary psychoanalytic approach. Further, the emphasis on the liberation from repression can be interpreted as a critique of social oppression, and fascism. 
It is well-known that this was the starting period of the debates in the history of psychotherapy and psychoanalysis about the boundaries and frames of therapist-client relationship (Baur, 1997). In the background of these debates one can find the unveiling of the "couch confusions" (conflicting relationships between e.g. Jung and Sabina Spielrein, Otto Rank and Anaïs Nin, Sándor Ferenczi and Elma Pálos). There was also a theoretical-technical and personal opposition between Freud and Ferenczi about the handling of transference and counter-transference along the ,abstinence versus affectionate relationship" dimension (Haynal, 1988).

This is worth of attention to see these ambivalences in the psychotherapy and in the relationship of Hillesum and Spier. Although they involved emotionally and sexually and had an intimate relationship, they tried to protect the boundaries, keeping a „dual relationship":

He had pulled himself together and deliberately adopted a matter-of-fact attitude; but he too had had quite a struggle. And he asked, "Did you think about me this week ? " And when I made a few noncommittal remarks and lowered my head, he said, very honestly, "I must honestly tell you that I thought a lot about you the first few days of this week. (Hillesum, 1996, 22)

Our question now is how this questionable therapeutic technique and ethically problematic dual relationship contributed to the personality development and spiritual growth of Etty Hillesum.

\section{Lived experiences transformed into embodied spirituality}

The holistic treatment of Spier did not involve only the body and the charismatic personality of the therapist for the liberation of desires, but it was also extended to the psychological-spiritual territories. Spier had a strong attachment to mysticism and to the mystical Christian authors. He introduced Etty the works of Saint Augustine of Hippo 
and recommended her to read the Bible. Spier's wide knowledge of love and sexuality might help Etty to transform her sensual, erotic experiences into personality development:

I am not really in love with him. He captivates and sometimes fascinates me as a man, and I am learning an unbelievable amount from him. Ever since I met him, I have been experiencing a process of maturation, something I would never have thought possible at my age. (Hillesum, 1996, 26)

Spier suggested Etty to write a diary to understand herself but also to take responsibility for herself, and encouraged her to reach a deeper self-understanding. Etty was overwhelmed by having the chance to organize Spier's library of one thousand books, and partly storing it because there was no enough space for the books in Spier's flat. Etty called the library a "mysterious temple of wisdom".

Spier advised Etty to adhere to the following spiritual practice: read philosophy, poetry, and Biblical texts, meditate, contemplate and worship. He recommended her mainly the texts of Jung, Rilke, and the Bible. Rilke's poems made an enormous influence on Etty. She quoted them very often in the diary, but also felt a deep empathy for the poet and borrowed words and phrases from him when she couldn't find proper ones to express herself. She felt Rilke was always with her as a kind of a soul mate. Spier taught Etty the meditative reading of Rilke's poems and she used this technique to find order in her life. It was Rilke's influence which turned her to the "inner world" - with Rilke's term, the „Weltinnenraum" -, which meant the inner Universe, the interiorization of the outer space for her. The feeling of identification was strengthened by the fact that Rilke was of similar age as Etty when he wrote these poems and also had strong affections to Russian culture. Etty met Rilke's Prayers of a young poet in Spier's library which became an important incentive for her inner dialogues between erotic, spiritual, and esthetic impulses. This book remained the most important reading for her 18 months later as well, even in the Westerbork camp, the anteroom of death. 
Spier (and Rilke) taught Etty to remain "undestroyable" despite the general collapse around her. After the order to have on the Jewish badge she writes on May 18. 1942:

The threat grows ever greater, and terror increases from day to day. I draw prayer round me like a dark protective wall, withdraw inside it as one might into a convent cell and then step outside again, calmer and stronger and more collected again. I can imagine times to come when I shall stay on my knees for days on end waiting until the protective walls are strong enough to prevent my going to pieces altogether, my being lost and utterly devastated. (Hillesum, 1996, 133-134)

At the beginning she struggled a lot to be able to keep intact her connection to reality despite her mood swings originated from her encounters with the "chaos", the "wicked" and "sorrow". In order to protect the reality of Reason from the chaotic influence of the Nazi regime, she leaned - mostly at the beginning of the diaries - on Spier. She wrote down his notes, borrowed words from him (like from Rilke and other authors). These thoughts and the attachment to Spier helped Etty to cope with her depression:

Yesterday afternoon we read over thenotes he had given me. And when we came to the words, "If there were only one human being worthy of the name of 'man,' then we should be justified in believing in men and in humanity,"I threw my arms round him on a sudden impulse. (Hillesum, 1996, 11)

The first notes in her diary introduce a rather self-focused young woman, reflecting that she almost exclusively dealt with her overwhelming admiration for Spier. She never gave up this strong attachment but her attitude changed gradually. While at the beginning of the diary she is fantasizing about marrying Spier and owning him, later she leaves this fantasy, elaborates her longing by writing but remains committed to Spier until his death in 1942. One can follow the transformation of her feelings - in Erich Fromm's (1956) terms the process of change from romantic love to mature love - and its facilitating effect on her personal development in this note from the diary:

And so I wanted to own him, and I hated all those women of whom he had spoken to me; I was jealous of them, and perhaps wondered, although not consciously, what part of him was left for me, and felt that I had no hold over him after all. These feelings were really petty, not on a high plane at all, but I did not realize that at the time. All I felt was wretchedly unhappy and lonely - I realize why now 
- and all I wanted was to get away from him and to write. I think I know what all the "writing" was about as well: it was just another way of "owning," of drawing things in more tightly to oneself with words and images. And I'm sure that that used to be the very essence of my urge to write: I wanted to creep silently away from everyone with all my carefully hoarded treasure, to write it all down, keep tight hold of it, and have it all to myself. And this grasping attitude, which is the best way I have of describing it, suddenly fell away from me. A thousand tyrannical chains were broken, and I breathed freely again and felt strong and looked about with shining eyes. And now that I don't want to own anything any more and am free, now I suddenly own everything, now my inner riches are immeasurable. (Hillesum, 1996, 15-16)

The introspective tone remains present all along in the diaries, but Hillesum's attention is opening gradually from herself to the outer environment. She is manifestly aware of the persecution and deportation of Jewish people and reacts in three ways: feels the responsibility to recording, diarizing the persecution, develops a spiritual form of suffering in herself, and creates an own image of God, and a worship practice. She considers writing as a potential form of resistance, similarly to Anne Frank, or Simone Weil.

Eroticism always occupied a substantial space in the fantasy-world and mental life of Hillesum. In the diaries she describes in detail her parallel relationships with her landlord, Han Wegerif and with Julius Spier, but also speaks about her attraction to Spier's fiancée. As we could also see in the quotation above, she gradually recognizes that she doesn't have to exclude erotic feelings from her life in the sake of spiritual self-fulfillment, but it is enough to give up possessiveness (See also Fromm, 1976).

Spier died on 15. September in 1942, one day before he would have been transported by the Gestapo to the Westerbork camp. One might find paradoxical Etty's reflection on it, but in the light of her spiritual transformation these thoughts are rather congruent and come up to the memory of her mentor:

Am I expected to put on a sad or solemn face? I am not really sad, am I ? I would like to fold my hands and say, "Friends, I am happy and grateful, and I find life very beautiful and meaningful. Yes, even as I stand here by the body of my dead companion, one who died much too soon, and just when I may be deported to some unknown destination. And yet, God, I am grateful for everything. I shall live 
on with that part of the dead that lives forever, and I shall rekindle into life that of the living that is now dead, until there is nothing but life, one great life, oh God." (Hillesum, 1996, 203).

This note also reflects that Hillesum's mysticism ensues from an erotic background. Eroticism cannot be explained here with the Freudian Eros, libido, and desire concepts but also with the passion which can be connected to suffering and pain. The desire for the fusion with the Other in this case originates from the desire for homonomy (Angyal, 1939). This phenomenon can be also described by the Aristotelian concept of participation which is realisation of ultimate humanity in the acts of friendship and fraternity (Ross, 2001).

\section{From erotic sensuality to the ontological mode of life}

The common dimension of suffering and erotic desire is passion - from the Latine passio, Greek pathos - cannot come into existence without the acceptance of vulnerability which contains the openness to the Other's influence. The unselfish erotic sensuality (an aspect of mature love in Fromm's sense) and the openness for the experience of suffering can result in vulnerability because in these situations the person risks losing control and powerlessness, and these are not far from defencelessness and dependency. Etty Hillesum recognized the connections between her sexual experiences and her growing spirituality. Her solution was not the Freudian sublimation of the sexual drive, but its liberation in the sake of love for mankind. With this attitude Hillesum followed the teachings of Julius Sipier and presumably those of Wilhelm Reich (1963), and the contemporary bodypsychotherapy movement in the background. The key for the spiritual potential of human sexuality can be found in passion which provocatively connects the ability for self-giving in an erotic relationship, with self-giving to suffering, and the capacity for containing others' suffering (Gaillardetz, 2009). Hillesum's eroticism in this way does not only follows her spiritual growth but deepens and embodies it. That's why she cannot be considered as a real mystic because she does not turn away from the world but embraces it. Neither does she relinquish sexuality or bodily experiences for the sake of spiritually motivated celibacy. 
Etty's diaries and letters also reflect - quasi as a premonitory sign of sexual revolution on the contemporary problems of the disgregation of modern the modern family. At the beginning she thinks that the task of a woman is to show the way to the soul of the man. She did not accept traditional masculine roles but she considered - very likely under the influence of Julius Spier - a 'real man' those who had a 'feminine soul'. Also her admiration for Rilke can be traced in this opinion in the regard that Rilke also emphasized the fraternity and union of men and women. Etty's second diary starts with topic on 4. August in 1941, referring to Spier:

$\mathrm{He}$ is a mature fifty-five-year-old and has reached the stage where he can love all mankind, having loved many individuals in the past. I am an ordinary twentyseven-year-old girl, and I too am filled with love for all mankind, but for all I know I shall always continue to be in search of my one man. And I wonder to what extent that is a handicap, a woman's handicap. Whether it is an ancient tradition from which she must liberate herself, or whether it is so much part of her very essence that she would be doing violence to herself if she bestowed her love on all mankind instead of on a single man. (I can't yet see how the two can be combined.) Perhaps that's why there are so few famous women scientists and artists: a woman always looks for the one man on whom she can bestow all her wisdom, warmth, love, and creative powers. She longs for a man, not for mankind. (34)

A particular paradox of Etty's life situation was that she lived in an uncertain present: only her future was sure as she new that she would be killed. This dramatic contrast can be found found between her writings and those of others who were in similar situation but reflect as survivors on the posttraumatic growth they experienced after this extremely destructive situation. Hillesum's viewpoint is not retrospective: she always returns to herself and the transcendence she founds there. This helps her to remain in the terribly dreadful presence. She has a strong positive attitude towards life which she thinks as nice and meaningful despite all the terrible circumstances.

Although more offered her to give refuge and hide her, she went to the Westerbork transit camp of her own will 'to take on community with the fate of her people'. She worked as a volunteer in the camp's hospital. As she had a permission to go out to Amsterdam, she 
could mediate between the camp and the resistence movements. In 1943 though, when the Jewish Ciuncil was dissolved, she lost the possibility to travel to Amsterdam, so she couldn't write limitless number of letters. But still then she kept her holistic, balanced view of the world:

People sometimes say, "You must try to make the best of things." I find this such a feeble thing to say. Everywhere things are both very good and very bad at the same time. The two are in balance, everywhere and always. I never have the feeling that I have got to make the best of things; everything is fine just as it is. Every situation, however miserable, is complete in itself and contains the good as well as the bad. All I really wanted to say is this: "making the best of things" is a nauseating expression, and so is "seeing the good in everything." (327-328)

Etty's diaries and letters also enlighten the process of a dramatic breakthrough and the attitude-change leading to a turn-of-fate in a person's life. Further they clarify the paradox of how one can keep a constructive and positive attitude amongst a worldwide traumatic schock and lethal threats. She gives a direct example for the authentic human existence, and how it is created from self-reflection and the need of the pursuit for order and meaning, when everything is collapsing around the individual - and in this case that was what happened.

Several authors think that Hillesum's writings can be well interpreted in the framework of Eric Voegelin 'spiritual' realist' philosopher's theory (see e.g. Coetsier, 2008). According to Voegelin the dread of Nazism not only calls our attention to think and speak differently, but also to be different (Voegelin, 2014). Etty Hillesum's stance of staying in the here and now is very similar to Voegelin's concept of the 'flow of presence', without a philosophical contextualisation.

This approach has a strong resemblance also with the phenomenological-existential theory of Viktor Frankl, who, based on his experiences in the concentration camp, centers suffering as an experience which might bring the person closer to the quest of inner essence and meaning (Frankl, 2006). An important difference, though, that Frankl was a survivor, and his work about the quest for inner essence and meaning he created after his 
return from the Auschwitz. Hillesum's case have more similarities with Simone Weil, who starved to death in London in 1943, or with Anne Frank, who died in Bergen-Belsen in 1945.Their works are all saturated with the ,flow of presence', calling attention to the importance of self-reflection, writing, and dialogue. Writing (of diaries, blogs, selfreflections) is also considered as a useful tool of elaborating traumas by the contemporary psychological literature (Pennebaker \& Evans, 2014). Writings which were born in the most extreme situations, like Hillesum's, very sharply prove that one of the important tool of coping is the endeavour to preserve humanity through a dialogue with a (transcendent) Other, and through the creative activity of writing. Etty Hillesum's diaries and letters also give an example for the outstanding role of empathy, the caring for others and the relational existence which can contribute to the experience of beauty even among most terrible circumstances.

The love for life compelled Hillesum to turn away from the Nazi horror to the world of her diary which took place in the transitory zone of time and timelessness (Coetsier, 2008). Probably this 'transitory existence', this particular state of flow made it possible for her to see the essence which cannot be seen if one perceives reality only in a static motionlessness, and expects only this from reality. Hillesum is not an idealist, she is not driven by some mystical irrationality, not the abstract forsaking from reality but the conscious experience of here and now reality, the direct encounter with the drama of humanity, and the finding of the unique adequate solution. Not universally unique, but the only solution for the given individual in search of meaning.

The connection to the "flow of presence" can be realized in its strongest form in the state of crisis (Coetsier, 2008). The non-static nature of existence can be seen the best then. That's why many people feel the quest for the positive meaning in a critical life-situation a transcendent, or even mystical experience. Some people after a life-threatening illness or serious trauma experience a rebirth which can be explained by the transformation of their attitudes during the quest for meaning. In the case of Hillesum it was the most direct and realistic experience of the inner space - the closest connection to reality and not the commonsense drawing away from it - helped her to get connected to others as well, not 
focusing only on herself. She felt that if there is no chance for political and other community resistance, than an other act of resisting against indignity is needed which she found in the turn of hatred into love. She thought that this could be realized through the experience of one own and others' suffering. However this is not a masochistic wish for suffering. Hillesum recognized that if suffering is not avoidable then it could be transformed into a more extensive vision about life. This also implies the acceptance of death as an unavoidable component of human existence. As Irvin Yalom writes:

'Death awareness may serve as an awakening experience, a profoundly useful catalyst for major life changes.' (Yalom, 2008, 30)

and referring to St. Augustine:

It is only in the face of death that a man's self is born..... Although the physicality of death destroys us, the idea of death saves us. (Yalom, 2008, 32-33)

According to Heidegger (1962) the acceptance of death makes it possible the transference from a more superficial life to the state of conscious existence. This is the essence of authentic existence where one can face the possibilities and obstacles of existence. Following Heidegger, existentialist psychotherapists define two modes of existence (Yalom, 2008): One is the ,everyday mode” when the individual deals with achievement, physical appearance, possessions, or prestige. In the „ontological mode”, however, one is prompted to construct an authentic life with meaning, connectivity and responsibility. It is noteworthy that existentialists emphasize the importance of the awareness of mortality in this process, and also that the person in the ontological mode is more primed to make significant changes.

Etty's paradoxical case - her personal and spiritual development among the most adverse circumstances - can be also explained by those theories of loss and trauma which deal with the reactions given to "shattered assumptions" (Janoff-Bulman, 2004) and to the „loss of the assumptive world" (Kauffman, 2002). These theories propose that the collapse of the person's world-view after a trauma, loss, disease or other strong stressor, 
may turn the individual to existential questions, and might be a starting point for spiritual development (Tedeschi \& Calhoun, 2004). These changes however, have not been observed only among religeous persons. According to these models the deepening spirituality can reorganize the value system and strengthen the relationship with people and reinforce transcendent attitudes.

\section{Conclusions}

This extraordinary story can be hardly fit in the conventional psychological models of coping. Etty Hillesum's case cannot act either the part of a generalizable example or a typical model because of the circumstances overwriting rationality, and its moral connotations pointing beyond everydayness. This case is rather metaphorical than prototypical. However this unique example may help the reader to contemplate about the dilemmas of authentic and free choice, and the possibilities of coping and growth even in their own life. Etty, this young woman tuned herself without fear to the flow of life through her experience of the here and now in the context of the unthinkable terror of the Nazi genocide. In the collapsing world her pasychological integrity was built up from her faith in human goodness and the strength of relationships. She kept her self-coherence supported by creative writing, and tried to reach a "nomadic consciousness". Her responses demonstrate the possibilty of authentic action, but do not the represent an ideal or only solution (for this there might be other possibilities of resistance, escape, and any trials for the protection and saving of life). The lesson however, or at least the provoking food for thought from Etty Hillesum's case, might be that there is always a possibility for personal growth and the search for meaning, even among the most extreme circumstances, where seemingly all reason and meaning is lost.

\section{Bibliography}

Angyal, A. (1939). "The structure of wholes". Philosophy of Science, 6 (1): 25-37. Avila, L.A. (2003). Georg Groddeck: Originality and exclusion. History of Psychiatry, 14/1. 2003, 83-101. 
Baur, S. (1997). The Intimate Hour: Love and Sex in Psychotherapy. Houghton Mifflin.

Coetsier, M.G. S. (2008). Etty Hillesum and the flow of presence : a Voegelinian analysis. Columbia: University of Missouri Press.

Frankl, V. (2006 / 1946). Man's Search for Meaning. An Introduction to Logotherapy, Boston: Beacon Press.

Fromm, E. (1956). The Art of Loving New York Harper \& Row.

Fromm, E. (1976). To Have Or to Be? New York: Harper \& Row.

Gaillardetz, R.R. (2009). Sexual vulnerability and a spirituality of suffering: Explorations in the writing of Etty Hillesum Pacifica: Australian Theological Studies 22(1): $75-89$.

Haynal, A. (1988). The Technique at Issue: Controversies in Psychoanalysis from Freud and Ferenczi to Michael Balint. London: Karnac Books.

Heidegger, M. (1962). Being and Time. Oxford: Blackwell.

Hillesum, E. (1996 / 1981). An Interrupted Life: The Diaries of Etty Hillesum, 1941-1943. New York: Henry Holt and Company.

Janoff-Bulman, R. (1992). Shattered Assumptions. New York: Free Press.

Kauffman, J. (2002) (Ed). Loss of the Assumptive World: A Theory of Traumatic Loss. London: Routledge.

Mizrachi, N. (2001). From causation to correlation: The story of Psychosomatic Medicine 1939-1979. Culture, Medicine and Psychiatry, 25: 317-343.

Pennebaker, J.W. \& Evans, J.F. (2014). Expressive Writing: Words that Heal. Idyll Arbor, Incorporated.

Reich, W. (1963). The Sexual Revolution: Toward a Self-Governing Character Structure. New York: Farrar, Straus and Giroux.

Ross, W. D. (2004). Aristotle. $6^{\text {th }}$ edition. London: Routledge.

Spier, J. (1944). The hands of children : an introduction to psycho-chirology. London: Routledge \& Kegan Paul.

Tedeschi, R. G., Calhoun, L. G. (2004). Posttraumatic Growth: Conceptual Foundations and Empirical Evidence. Psychological Inquiry. 15(1). 1-18.

Voegelin, E. (1987). The new science of politics: an introduction Chicago: University of Chicago Press.

Woodhouse, P. (2009). Etty Hillesum: A life transformed. London: Bloomsbury Academic.

Yalom, I.D. (2008). Staring at the sun. Overcoming the Dread of Death. Piatkus. 